\title{
A Carta Guarani Kaiowá e o direito a uma literatura com terra e das gentes Marília Librandi-Rocha ${ }^{1}$
}

\author{
Queremos que todos vejam \\ Como a terra se abre como flor
}

Canto guarani

(trad. Douglas Diegues)

Venham então.

Venham.

Retirem a terra,

O barro do buraco.

Ele está todo cavado.

Eu o fiz fundo.

Não podem ouvir talvez meu chamado?

Popol Vuh (vv. 1.247-53)

O herói Cipacna, do poema maya-quiché citado na epígrafe, que nos interpela do fundo do buraco, não está, como pensam seus adversários, cavando sua sepultura, mas "um abrigo para ele próprio" (v. 1.244). É para falar da terra, abrigo e sepultura, mas também barro e flor, que esse artigo versa sobre a Carta Guarani Kaiowá (2012), o texto de denúncia de violação dos direitos humanos que maior impacto causou na sociedade brasileira da primeira década do século XXI. ${ }^{2}$ Assinada por cinquenta homens, cinquenta mulheres e setenta crianças da comunidade Pyelito Kue/Mbarakay, acampada à margem do rio Hovy (pronuncia-se "Jogui"), em Iguatemi, Mato Grosso do Sul, em 8 de outubro de 2012, a carta se espalhou pelas redes sociais e gerou um movimento de reação e solidariedade sem precedentes, pois ganhou não apenas defensores de uma causa em comum, mas milhares de coautores brasileiros e estrangeiros que adotaram o nome Guarani Kaiowá como parte de sua família extensa (Brum, 2012b). Este artigo relembra os passos principais do episódio e sugere avançarmos um passo a mais ao propormos a inclusão da Carta Guarani Kaiowá das comunidades Pyelito Kue/Mbarakay no âmbito da literatura contemporânea

\footnotetext{
${ }^{1}$ Doutora em teoria literária e literatura comparada e professora de literatura e cultura brasileiras na Universidade de Stanford, Califórnia, Estados Unidos. E-mail : mariliar@stanford.edu

${ }^{2}$ A carta foi divulgada primeiramente pelo site do Conselho Missionário Indigenista (Cimi), no dia 10 de outubro de 2012, acompanhada de relatório da Assembleia Geral Guarani, Aty Guasu.
} 
produzida no Brasil. Começo, assim, por retomar o incisivo texto escrito por Eliane Brum (2012a) no calor dos acontecimentos que envolveram a repercussão da Carta e que terminava com a indagação: "para nós o que é a palavra?" Transpondo essa questão para o campo dos estudos literários, indago: para nós o que é e o que pode a palavra indígena no cerne da literatura escrita no Brasil? A primeira parte deste artigo discute a concepção de literatura que nos orienta, qual sua relação com os direitos humanos e de que modo uma carta indígena pode afetar a história literária brasileira. A segunda parte contextualiza a história dos Guarani, o processo de que foram vítimas, e termina com uma análise que ressalta o impacto literário da Carta e o vínculo entre direitos territoriais indígenas e direito à autoria.

Escrita como reivindicação territorial, solicitando o direito à morte na terra dos antepassados, e destinada às autoridades do Governo e da Justiça do Brasil, a Carta Guarani Kaiowá se institui, de fato, como um dos textos mais poderosos da contraconquista. E é para falar da força poética e política da Carta que este texto caminha do direito de habitar a terra, solo em que se vive, ao direito de habitar as palavras, "solo árduo/ mas alado" (Baptista, 2011, p. 119) em que se escreve. Para estabelecer o trânsito do papel da terra à terra do papel, "recorro ao testemunho de dois indígenas guarani (ñandeva) do Mato Grosso do Sul, Hipólito e Epitácio. Para eles, a palavra ritualizada dos guarani "tem terra", ijyoýva, ao passo que a dos cristãos "tem papel", ikuatiáva" (Chamorro, 2008, p. 279). Até o momento, as respostas governamentais continuam a ter papel, mas não terra, ${ }^{3}$ e este texto propõe que o campo discursivo da literatura pode dar uma resposta "com terra", à altura do apelo guarani, que, no cerne da América Meridional, também nos interpela do fundo do buraco, ecoando, de modo trágico, os versos do grande poema cosmoépico dos povos quichés da Mesoamérica. ${ }^{4}$

\footnotetext{
${ }^{3}$ No momento em que escrevo, as terras Guarani Kaiowá de Pyelito Kue/Mbarakay foram reconhecidas por relatório da Funai publicado no Diário Oficial da União em janeiro de 2013, mas sua efetiva homologação não se efetivou. Notícia mais recente, de $1^{\circ}$ de março de 2014 , veiculada pelo Cimi, denuncia novo ataque de pistoleiros contra a comunidade e especifica: "O tekoha Pyelito Kue/Mbarakay é parte de área identificada com 41.571 hectares de extensão pelo Grupo de Trabalho (GT) da Bacia Iguatemipeguá, localizada nas proximidades da Terra Indígena Sassoró. A fazenda Cambará é apenas uma das várias propriedades incidentes sobre a área identificada."

${ }^{4}$ O Popol Vuh, como explica Gordon Brotherston (2007), é “conhecido por muitos como 'a Bíblia' do continente [...] Escrito apenas três décadas apos a invasão do território quiché liderada por Pedro de Alvarado em 1524, o Popol Vuh procura afirmar memória e direitos locais. [...] Chega também a iluminar e a ser iluminado por cosmogonias clássicas do Quarto Mundo para além da Mesoamérica,
} 


\section{Parte I - Uma literatura com terra}

O primeiro problema a ser enfrentado é o de não considerar ficção um documento do real e, sobretudo, um documento traumático do real. A Carta Guarani Kaiowá não pertence de modo algum ao campo do ficcional, mas pode pertencer ao campo do literário, assim como a carta de Pero Vaz de Caminha, as Cartas Jesuítas, os Sermões do Padre Vieira, os muitos tratados descritivos, relatos de viagem e outros documentos histórico-sociais que integram o acervo da literatura produzida no Brasil, ${ }^{5}$ pois alcançaram uma dimensão que ultrapassou seu território de inscrição inicial. Essa é a concepção de literatura proposta por Luiz Costa Lima (2006), a de ser um campo discursivo "heterogêneo", que inclui o que ele chama de "formas híbridas", como a carta, o ensaio, o livro de máximas, os diários e a autobiografia, os quais, mesmo não tendo uma destinação poético-ficcional primeira, podem ser incorporados ao acervo literário caso apresentem um elemento de destaque em relação a outros textos similares. Assim, se centenas de cartas escritas por grupos indígenas têm circulado atualmente pelas redes e são parte da história presente de reivindicação social e territorial desses povos, por que a Carta Guarani Kaiowá de Pyelito Kue, especificamente, causou tanta comoção popular, senão porque ela apresenta uma qualidade diferencial que precisa ser descrita?

como o Watunna do Caribe, a Lenda do Jurupari do Rio Negro e o Ayvu Rapyta guarani, que compartilham a sua forte consciência sobre a riqueza biótica e imaginativa da floresta tropical da América (Brotherston, 2007, p. 11-12). E ainda: "como tantos outros documentos nativos da Mesoamérica do século XVI, este foi composto por uma comunidade local ou, talvez, por uma parte dela, a facção kavek da cidade de Santa Cruz Quiché, Guatemala, para reclamar, perante o governo colonial espanhol, um beneficio ou privilégio que datava de uma época anterior à invasão" (Brotherston, 2007, p. 13). No Brasil, lembra Brotheston: "Affonso Romano de Sant'Anna produziu [...] um 'moderno Popol Vuh', no qual a obra maia-quiché dialoga com os textos guaranis do Brasil (A grande fala do índio guarani perdido na história, 1978)."

\footnotetext{
${ }^{5}$ Classificada como literatura de informação, crônica histórica ou literatura de viagem, a Carta de Caminha, ganhou outro realce a partir da poesia Pau-Brasil, de Oswald de Andrade. Para José Aderaldo Castello, "desde que foi reconhecida pelos modernistas brasileiros, deixou de ser apenas um documento histórico. [...] Transformou-se num foco de renovação afetiva, de permanente vibração, ao mergulharmos no passado, em busca das emoções iniciais das nossas origens" (1999, p. 55). Afirmação semelhante encontra-se em uma das mais recentes histórias literárias, a de Luiz Roncari: "a Carta de Caminha, ainda que seja um texto de informação, tem um valor literário que vai além das qualidades de estilo" (2002, p. 42). Para uma abordagem da recepção da Carta na historiografia literária brasileira, ver dissertação de Fabio William Lopes Braga (2009).
} 
É isso que constitui, na bela expressão de Costa Lima, o "caráter errático do campo da literatura" (Costa Lima, 2006, p. 336), ou seja, "a possibilidade de uma certa obra mudar sua inscrição originária" (Costa Lima, 2006, p. 348, grifos no original). Assim: "Fora da ficcionalidade, a literatura abrange aquelas obras que, perdida sua destinação original, recebem outro abrigo, i.e., mantêm seu interesse, mudando de função" (Costa Lima, 2006 p. 347). Retenho aqui a expressão "receber outro abrigo", pois é disso que se trata neste texto em relação à Carta Kaiowá: a de que, mesmo passado seu momento de atuação, essa carta continuará a manter seu interesse, mudando de função como "Carta da Literatura Indígena produzida no Brasil". Defendo, então, a ideia de que a reivindicação da terra que lhes pertence não deve estar separada do território da literatura a que também tem direito. ${ }^{6}$ Com isso em mente, posso dizer que a destinação primeira da Carta Guarani não era e continua não sendo literária, mas, sim, um documento político e social de denúncia e pedido de socorro. No entanto, a impressão que se tem é que a alta receptividade que alcançou está vinculada à força da linguagem que a caracteriza: "Pela espessura da linguagem, a literatura então se tornará sua segunda morada. Tal mudança de lugar não será um gesto caritativo. Para que se cumpra, será preciso que a obra traga consigo um traço de destaque" (Costa Lima, 2006, p. 350). Esse traço de destaque, como mostrarei na segunda parte deste texto, vincula-se ao modo como seus enunciadores apelam a morte. Como se verá, é justamente esse apelo que opera a torsão que transforma essa carta em carta da literatura. ${ }^{7}$

Diria, então, que este texto propõe a inclusão da Carta Guarani Kaiowá nos domínios territoriais da literatura contemporânea seguindo a mobilização pela efetiva homologação de suas terras, tekoha, em Mato Grosso do Sul, pois considera que o direito ancestral a suas terras é paralelo ao direito de inclusão no terreno discursivo literário. A posse de suas terras não deveria, pois, estar dissociada do abrigo do terreno literário, sobretudo porque, na cosmovisão guarani, terra e palavra e alma não estão dissociadas, como mostraremos na leitura da Carta. É possível, inclusive, dizer que aquilo que chamamos qualidade literária

\footnotetext{
${ }^{6} \mathrm{O}$ vínculo entre literatura indígena e questões territoriais é defendido por Lucia Sá, autora do importante estudo Rain Forest literatures, 2004.

${ }^{7}$ Não posso deixar de notar que, se alguns políticos se matam para entrar na história, grupos como os Kaiowá solicitam sua morte, e inclusive se matam, para sair da história que tanto os oprime. Por isso também, literatura é caso de vida e de morte, como a análise da carta na segunda parte vai realçar.
} 
remete, em termos guaranis, como no depoimento citado anteriormente, a uma palavra "com terra", e não apenas "com papel". Sugiro, assim, o direito à literatura como território discursivo acolhedor.

\section{Literatura e justiça}

Essa sugestão, no entanto, esbarra em um questionamento a respeito dos limites do literário em confronto com discursos minoritários. $\mathrm{Na}$ crítica literária brasileira recente, tal debate foi proposto por Marco Piason Natali, no texto "Além da literatura" (2006), o qual, por sua vez, dialoga criticamente com texto de Antonio Candido, publicado em 1988, "O direito à literatura" (2004). Meu acesso a essa discussão deu-se através de Jaime Ginszburg, que em seu livro Crítica em tempos de violência (2012), sintetiza a questão ao dizer que: "A necessidade de pensar contemporaneamente nos direitos de sociedades e grupo excluídos pela violência histórica leva a colocar a pergunta primária - o que entendemos por literatura - no âmbito do questionamento dos paradigmas civilizatórios" (Ginszburg, 2012, p. 204).

$\mathrm{O}$ texto de Candido entende literatura no sentido amplo como "fabulação" e termina por reivindicar a difusão da literatura canônica, seu valor educacional e de formação crítica como um direito constantemente negado em países a exemplo do Brasil, no qual a maioria da população não é ensinada a ler e a escrever. A visão humanista socialmente engajada de seu texto (escrito antes da década de explosão dos estudos culturais), correta em defender a participação dos grupos excluídos na cultura letrada, partilha, no entanto, da visão da literatura europeia como paradigma do universal, principal crítica que a ele faz Natali. Além disso, complemento, sua visão está vinculada a uma concepção teleológica e evolucionista, que considera expressões populares e/ou folclóricas como estágios primitivos frente aos sistemas avançados eruditos europeus, como fica claro na frase: "fruí-la [refere-se à criação ficcional] é um direito das pessoas de qualquer sociedade, desde o índio que canta suas proezas de caça ou evoca dançando a lua cheia, até o mais requintado erudito [...]" (Candido, 2004[1988], p. 180). Ou seja, seu texto não imagina que "o índio que canta" possa também ser produtor de textos e erudito, pois a concepção de texto restringe-se ao modelo herdado. ${ }^{8}$ Aqui, seria preciso lembrar, como contraponto, a

\footnotetext{
${ }^{8}$ Para outros exemplos dessa abordagem em Candido, ver estudo de Anita de Moraes (2012).
} 
proposta que o antropólogo Antonio Risério defendera já em 1993, sobre a ampliação da noção de literatura como devendo também incluir poéticas e práticas de competência ágrafa extraocidentais no mesmo patamar de valoração.

Já o texto de Natali vincula-se aos debates mais recentes oriundos dos estudos culturais que surgiram com força na academia norteamericana na década de 1990, junto com a reflexão marxista renovada pelos estudos pós-coloniais e que, de certo modo, estabeleceram uma cisão entre crítica literária voltada para o cânone ocidental e abordagens sócio-políticas minoritárias. ${ }^{9}$ Seu texto entende literatura como um campo minado pela noção de um "universal" harmônico e termina por sugerir (de modo, como ele mesmo diz, "perverso") que justiça e literatura não estariam necessariamente vinculadas, pois a própria noção universal do literário produz uma "violência tradutória", que elimina as diferenças ao incluí-las. Assim:

Chamar de literatura ou ficção o que é outra coisa seria, portanto, uma forma dessa violência tradutora que abafa a diferença contida naqueles horizontes conceituais que incluem outras formas de entender a relação com os objetos verbais, a representação da realidade e o lugar do sujeito humano na criação e recepção de textos [...] (Natali, 2006, p. 42).

Desse modo, se Antonio Candido defende o direito à literatura, entendida segundo o paradigma do universal e suas adaptações locais, Natali sugere o abandono do literário em prol de discursos que resistiriam ao concerto de um "universal" bem particular. Apesar, porém, dessa distinção, é importante notar que ambos os textos, o de Candido e o de Natali, têm em comum a recusa em incluir o texto "extraocidental", ameríndio, no caso, como parte da literatura. Para Candido, a inclusão não se coloca como problema, simplesmente porque não haveria "texto" indígena no mesmo patamar que o dos colonizadores e seus descendentes; para Natali, a inclusão corresponderia a uma "violência tradutora". Isso significa que a concepção de literatura é a mesma em ambos os autores. Tanto para um

\footnotetext{
${ }^{9}$ Os estudos culturais e pós-coloniais na academia norte-americana sofrem de várias cisões internas. O texto de Natali, por exemplo, se distingue, como ele mesmo aponta, da visão de literatura como passível de "escapar ao sistema", defendida por Gayatry C. Spivak (ver Natali, 2006, p. 32); ou das propostas de Gordon Brotherston e Lúcia Sá, que analisam como literatura textos e materiais ameríndios (Natali, 2006, p. 37), proposta similar à assumida neste texto.
} 
quanto para outro, a literatura é concebida como campo das semelhanças, apenas, e, como tal, serve ou para ser emulada ou para ser descartada. Olvidam (Candido por valorar a hierarquia discursiva, e Natali por justamente criticar essa hierarquia), assim, que a literatura moderna que nasce no final do século XVIII propõe-se como espaço discursivo de resistência, e campo em que diferenças em potencial emergem continuamente. Posso, então, traduzir o questionamento que estaria implícito em ambos os textos como: se a literatura é uma instituição europeia, que veio junto com a bagagem dos colonizadores das Américas, incluir uma carta indígena (ou de outros grupos minoritários) no mesmo barco, não seria uma contradição, ou, pior, um abuso?

\section{Uma literatura das gentes}

Entre essas duas vertentes, que afinal se unem, proponho seguir outra, uma terceira vereda: a de pensar o texto indígena dentro do campo literário, entendido como espaço discursivo de acolhimento e produção de diferenças, assim como venho buscando pensar uma teoria literária alterada pelo aporte do até então não literário (Librandi-Rocha, 2012).

Por isso, não sigo a solução de "imaginar um espaço além das fronteiras da literatura" (Natali, 2006, p. 42), primeiro porque o campo mesmo da literatura é já vasto o suficiente para incluir textos e concepções diversas e heterogêneas; segundo, por uma distinta concepção de política discursiva: considerar literatura apenas a de extração e inspiração europeia impede o diálogo no mesmo patamar de igualdade com outras formas de dizer. Nesse aspecto, é o mesmo argumento que diz que o pensamento dos indígenas não pode ser chamado filosofia porque não está escrito segundo o modelo da filosofia, que é ocidental. ${ }^{10} \mathrm{Na}$ perspectiva que advogo, incluir não quer dizer outorgar o direito, mas reconhecer a igualdade representativa.

Assim, não se trata de modo algum de "assimilação" ou de "integração" dos discursos indígenas, como se pensa a assimilação desses grupos na sociedade brasileira para que virem "brancos"; mas, ao inverso, trata-se de um retorno do indígena recalcado, como aqueles que assumiram o sobrenome Guarani Kaiowá como parte de si próprios. Por

\footnotetext{
${ }^{10}$ Essa concepção tem informado o campo da antropologia de Eduardo Viveiros de Castro (2002; 2004), que propõe uma operação tradutora; penso que à crítica literária também cabe essa tarefa tradutora.
} 
isso, volto a uma indagação básica: se as várias cartas dos europeus colonizadores são documentos de nossa literatura, por que a carta dos indígenas não poderia ser? Essa questão implica, sobretudo, um desafio para pensarmos outras possibilidades de histórias literárias. ${ }^{11}$ Vejamos.

\section{Outra história}

O texto do Formação da literatura brasileira (Candido, 1981) é claro: a "nossa" literatura nasce como a literatura dos senhores colonizadores, produzida "em terra inculta" para "nós", seus descendentes. ${ }^{12}$ Como já apontou Paulo Franchetti (2002), a leitura desse "nós" tornou-se, com os debates desconstrucionistas e dos estudos culturais, de difícil senão impossível digestão: quem não faz parte desse "nós" e não se inclui entre esses "descendentes" está hoje se multiplicando em políticas afirmativas de pertença à escrita da literatura e outras, sempre rasuradas. Pode-se assim dizer que todo o problema (ou solução) está em que "nós", hoje, não coincidimos necessariamente com a narrativa do "nós" que aparece no Formação. Lemos, ainda, no "Prefácio à segunda edição", de 1962: "Parece-me que o arcadismo foi importante porque plantou de vez a literatura do Ocidente no Brasil, graças aos padrões universais por que se regia, e que permitiram articular a nossa atividade literária com o sistema expressivo da civilização a que pertencemos, e dentro da qual fomos definindo lentamente a nossa originalidade" (Candido, 1981, p. 17). Diria que incluir a Carta Guarani Kaiowá (e outros textos indígenas) também significa "articular a nossa atividade literária com o sistema expressivo da civilização a que pertencemos", só que a civilização, no caso, é a aborígene e não apenas a europeia. Ou seja, trata-se de uma reivindicação de outra filiação. Pensar a Carta Guarani como parte do patrimônio da literatura contemporânea é, finalmente, estabelecer um matrimônio com outras

\footnotetext{
${ }^{11} \mathrm{O}$ que Monteiro diz sobre a historiografia indígena vale para nossa história literária: "De modo geral, a historiografia - sobretudo a brasileira - tem reservado ao índio o papel de figurante mudo ou de vítima passiva dos processos coloniais que o envolviam” (Monteiro, 1992, p. 476).

${ }^{12}$ Lê-se no "Prefácio à Primeira edição", de 1957: "tentativas muitas vezes débeis, outras vezes fortes, sempre tocantes, em que os homens do passado, no fundo de uma terra inculta, em meio a uma aclimação penosa da cultura europeia, procuraram estilizar para nós, seus descendentes, os sentimentos que experimentavam, as observações que faziam, - dos quais se formaram os nossos" (Candido, 1981, p. 10).
} 
formas de pensar e ser na territorialidade do Brasil. ${ }^{13} \mathrm{O}$ fato é que civilizações aborígenes sempre fizeram parte do programa da literatura brasileira; no entanto, os modos de sua inserção sempre foram via delegação: salvo engano, não há nenhum discurso aborígine, assinado por índios até o século XX, como parte da literatura brasileira, a não ser como citação, fonte ou inspiração. Trata-se, pois, de um lugar-comum desabitado, despovoado das gentes que intenta representar, situação que vem mudando radicalmente com a inserção de escritores indígenas e a multiplicação de estudos sobre as poéticas ameríndias no século XXI. ${ }^{14}$

\section{Literatura e não pertença}

No texto "Ainda brasileira?", Fernando Scheibe (2013) faz uma sugestão de longo alcance: abandonar o "sistema" e retornar às fontes das "manifestações literárias". A sugestão é rica em desdobramentos, pois nos convida a sair da marca e dos marcos da formação de um sistema literário nacional para repensar as produções contemporâneas fora de escola e de sistema, como manifestações de pluralidade, incompossíveis com a unidade nacional que dominou o pensamento da história literária no Brasil nos séculos XIX e XX. A inclusão de uma carta indígena impede o atrelamento imediato com o termo "literatura brasileira", pois ou é necessária uma ampliação do "brasileiro", de modo a incluir no âmbito de uma literatura escrita em português os indígenas e suas línguas; ou será preciso a desconsideração do termo, em prol de um mais amplo e genérico: textos literários produzidos no Brasil. Mas é de abolição que se trata, e também de reterritorializações.

\footnotetext{
${ }^{13}$ A ascendência guarani vincula-se às primeiras mães índias dos primeiros brasileiros e dos primeiros hispano-americanos na região Sul/Sudeste da América do Sul (Monteiro, 1992). Além disso, essa temática pode vincular-se ao debate sobre matriarcado que aparece em Oswald de Andrade e que vem sendo retomado atualmente (ver Aguilar e Nodari, 2010).

${ }^{14}$ Chamo atenção para alguns dos trabalhos acadêmicos que vêm sendo desenvolvidos atualmente, como o núcleo "Literaterras", da Universidade Federal de Minas Gerais, coordenado por Maria Inês de Almeida e Cinara de Araujo, e o trabalho de Sérgio Bairon, em parceria com comunidades de tradição oral indígenas e afro-brasileiras, no programa "Produção Partilhada do Conhecimento" (ECA/Instituto Diversitas na USP), além dos trabalhos de antropólogos, tradutores e poetas, assim como a significativa produção literária indígena em geral, de difícil acesso no mercado. Entre os nomes conhecidos, Ailton Krenak, Daniel Munduruku, Eliane Potiguara e Davi Kopenawa. No site de "Literaterras" (http://literaterras.wordpress.com/publicacoes/autoria-indigena) é possível acessar uma lista mais completa. Lembro, ainda, o importante "contradiscurso" de Luiz Ruffato na abertura da Feira do Livro de Frankfurt em 2013, denunciando o genocídio e a falta de representatividade indígena e afro-brasileira na literatura do Brasil.
} 
No caso, falar sobre a Carta Guarani Kaiowá significa alargar o horizonte para uma realidade regional, a da América do Sul meridional, e que envolve, portanto, as antigas áreas da colonização ibérica e as atuais fronteiras do Brasil, Paraguai, Argentina e Uruguai, assim como envolve o plurilinguismo português, espanhol, portunhol e os vários dialetos guaranis. É dentro desse paradigma que proponho a inclusão da Carta Guarani Kaiowá como manifestação da literatura contemporânea, entendendo literatura em um sentido ao mesmo tempo amplo e menor: aquele que nasce da não pertença. Fora, portanto, do âmbito nacional, mas dentro do campo literário. ${ }^{15}$ Assim, não seria mais uma literatura da gente, apenas, mas das gentes, "expressando a pluralidade e singularidade das diferenças de viver e representar o mundo" (Mota, 2011, p. 45).

Retomo, por isso, o debate proposto por Abel Barros Baptista, quando diz que o nacionalismo literário, que "impõe que a literatura que se faz no Brasil deve ser brasileira" (Baptista, 2009, p. 24, grifos no original), é em si mesmo um projeto romântico europeu de valorização do nacional, do exótico e da paisagem distante. No entanto, o que era para ser um projeto historicamente datado, tornou-se lei inalienável, graças à coincidência histórica do romantismo com a independência política do Brasil: "o acontecimento que realmente faz com que a autoridade do projeto romântico não se esgote na sua época histórica" (Baptista, 2009, p. 25). Devido a essa "coincidência de destinos" (Baptista, 2009, p. 28), não se consegue pensar a literatura fora da lei que vinculou o literário à representação da nação (segundo o modelo conciliador), que, por sua vez, está na base da dupla que tanta fortuna fez na crítica literária: o par localuniversal, já que "essa harmonia do local com o universal se institui igualmente por força do projeto nacional" (Baptista, p. 39). Hoje, porém, quando a visão harmônica da nação finalmente entra em crise, e o termo

\footnotetext{
${ }^{15}$ Quando esse texto já estava quase finalizado, caiu-me às mãos texto de Abel Barros Baptista (2009), no qual o conceito sobre o cosmopolitismo da literatura moderna é pensado "como abertura dum espaço de hospitalidade incondicional" (p. 67). Sem poder comentá-lo de modo mais detalhado, restrinjo-me a citar passagem fundamental para o argumento e o sentido do que busco expor ao falar do acolhimento da Carta no campo literário, sendo esse: "Não um espaço superior e restrito, para onde alguns poucos afortunados são cooptados, pela Unesco ou pelo sucesso comercial, formando alguma espécie de cânone supranacional ou literatura internacional; não um espaço homogéneo, universal, sem fronteiras nem conflitos, onde o espírito vagueia livre; não um espaço essencial de onde derivem e se deduzam todos os espaços, mais restritos e nada essenciais mas o espaço que se abstém de limitar e impor condições à entrada e estada do estrangeiro" (Baptista, 2009, p. 67).
} 
literário pode ser repensado em outras bases que ficaram abafadas, a lei ainda ameaça com a desagregação. A ameaça, mostra Baptista, é a de que “a própria literatura [...] desaparece se perde a referência ao seu fundamento e à garantia da sua existência [...]", pois, a lei da harmonia entre a criação literária e a realidade brasileira "torna ilegítima toda a tendência para encarar a possibilidade de a literatura resistir ao Brasil" (Baptista, 2009, p. 31). E ainda: "[r]omper essa harmonia significaria lançar a indeterminação sobre o destino da literatura brasileira: daí a força da lei" (Baptista, 2009, p. 31-32).

Diria, então, que o risco do gesto de inclusão da Carta Guarani Kaiowá só tem sentido e só tem valia se afrontar essa lei, lançando-nos voluntariamente na indeterminação: quando então percebemos que o que desaparece não é a literatura, mas uma ideia, uma proposta que virou lei. A Carta que leremos a seguir é também uma questão de lei. Ela diz: a justiça brasileira não nos representa e decreta a nossa morte; a literatura atrelada ao projeto romântico nacional também fazia isso: decretava a sobrevida literária dos índios já exterminados e olvidava os vivos (dentre eles, sobretudo os Guarani, que se tornam inimigos por causa da Guerra do Paraguai). Incluir a Carta Guarani Kaiowá é incluir os vivos, não brasileiros, e assim afrontar duas vezes a lei de fundação da literatura brasileira. Uma vez libertos da lei, poderemos pensar o que ficou rasurado. Antes ainda da leitura da Carta, dois pontos precisam ser brevemente expostos.

\section{Educação e tradução}

Em seu livro, Jaime Ginszburg sugere repensar a questão da literatura vinculada a projetos pedagógicos, como um "encaminhamento concreto" (2012, p. 205), que também considero fundamental. Incluir a Carta Guarani Kaiowá significa trabalhar para que estudantes brasileiros possam lê-la nas escolas e faculdades. Como diz Pedro Cesarino (2009),

a formação intelectual que começa no ensino básico não considera a existência das culturas ameríndias (para não falar das africanas ou asiáticas), preteridas em favor dos cânones euro-americanos. Essa negligência sistemática representa uma enorme perda para o conhecimento cosmopolita, que não estabelece acesso aos insondáveis mananciais de pensamento e criação indígenas. 
Para esse "conhecimento cosmopolita", a noção e a prática da tradução vêm fundamentando com uma parceria muito bem-vinda e de sucesso ético e estético entre antropólogos, poetas e críticos literários, trabalhando juntos na tradução dos cantos e narrativas afro-americanas, quilombolas e ameríndias. Um exemplo, entre muitos, é o trabalho da poeta e tradutora Josely Vianna Baptista (2011), que, em Roça barroca, traduz três cantos sagrados dos Mbyá-Guarani do Guairá, no Paraguai, parte do Ayvu Rapyta, seguidos de seus poemas "Moradas nômades (impressões e vestígios de viagem)". Como diz Francisco Faria, trata-se de um "projeto poético/político, que combina invenção artística, intervenção cultural, diálogo multidisciplinar e revisão (senão reavaliação) de nossa herança cultural" (Faria, 2011, p. 148). Esse projeto permite estabelecer um campo de diálogo (concebendo a literatura como língua franca) em que textos extraocidentais e ocidentais se alteram mutuamente. ${ }^{16}$

\section{Parte II - A Carta de Pyelito Kue/Mbarakai}

Os Kaiowá (junto com os Mbyá e Ñandeva no Brasil) são parte da grande nação Guarani que ocupava a América meridional e a região da bacia do rio da Prata quando da chegada dos espanhóis e portugueses no século XVI. ${ }^{17}$ Apesar do trauma da conquista que faz com que não se possa estabelecer continuidade entre os grupos "históricos" do século XVI e os "etnográficos" do século XX, há elementos do "modo de ser" Guarani que se mantêm recriados "frente a condições progressivamente adversas" (Monteiro, 1992, p. 475), "tais como o discurso profético e o profundo senso de identidade" (1992, p. 476). Caberia aos especialistas dizer se se poderia estudar a Carta Guarani Kaiowá como parte do "profetismo", pois parece plausível incluí-la na tradição dos discursos de resistência dos movimentos revoltosos que, desde o século XVI, uniam profetismo e discurso subversivo contra "o modo de vida imposto pelos karaí cristãos" (Monteiro, 1992, p. 485)

\footnotetext{
${ }^{16}$ No campo da prosa de ficção atual e sua relação com o mundo e as narrativas ameríndias, ver o estudo de Rita Olivieri-Godet (2012). No campo da poesia, ver antologia organizada por Sergio Cohn (2012) e que começa com os "Cantos Ameríndios".

17 "Do Chaco até o Atlântico, das capitanias do Sul até o rio da Prata, a presença guarani abrangia, no século XVI, uma imensa área que hoje inclui os estados brasileiros de Rio Grande do Sul, Santa Catarina, Paraná, São Paulo e Mato Grosso do Sul, além de parte dos países vizinhos" (Monteiro, 1992, p. 476-477).
} 
Os principais dados da história Guarani no período colonial remetem às reduções jesuíticas no contexto das colônias ibéricas (as primeiras reduções são fundadas em 1610), e ao bandeiritismo ${ }^{18}$ paulista no contexto regional brasileiro. Com as destruições das missões do Guairá entre 1628 e 1632 pelos paulistas, milhares de guaranis se deslocaram para São Paulo (calcula-se de 30 a 50 mil); e outros vão para as margens do rio Uruguai (cerca de $10 \mathrm{mil}$ ). Houve também um deslocamento das missões para regiões mais afastadas ao longo dos rios Uruguai e Paraguai. Esse contexto implica ao menos três coisas: os Guarani estão na origem da história de formação territorial do Brasil meridional; também estão na origem da constituição das populações do Sul e Sudeste - tanto o povoamento espanhol como o português se deram "por meio da incorporação de mulheres Guarani e a consequente emergência de uma população mestiça" (Monteiro, 1992, p. 482-3); e seus dialetos fizeram parte da chamada "língua geral" que tanto influenciou o português do Brasil.

\section{Os Guarani contemporâneos, e os grupos Pyelito Kue/Mbarakay}

A comunidade Guarani Kaiowá atual resulta da união de dois grupos: os Guarani, que se autodenominam Ñandeva, também chamados AvaChiripa, e os Kaiowá, que no Paraguai se autodenominam Pai-Tavytera. O terceiro subgrupo da etnia Guarani vivendo no Brasil e no Paraguai é formado pelos Mbyá. Os Kaiowás são o maior dos subgrupos Guarani, e "sempre habitaram o norte do Paraguai e o sul do Mato Grosso" (Almeida, 2001, p. 17). A história do contato com os não índios e a ocupação progressiva e sistemática de suas terras desde o século XIX19 reproduz o que Manuela Carneiro da Cunha bem sintetizou ao falar sobre o processo geral de desrespeito aos direitos indígenas no país: “Cada passo é uma pequena burla, e o produto final, resultante desses passos mesquinhos, é uma expropriação total" (Cunha, 2012, p. 82).

\footnotetext{
${ }^{18}$ Como adverte Monteiro, "o termo 'bandeirante' se trata de um anacronismo, pois não pertence a documentação do século XVII. A palavra entrou em uso em meados do século XVIII, inicialmente para designer expedições punitivas contra os índios em Goiás.” (Monteiro, 1992, p. 497)

19 Ver estudo de Antonio J. Brand (1998), que, em sua versão on-line, oferece um excelente abreviado da história do contato.
} 
As famílias das comunidades Pyelito Kue e Mbarakay, ${ }^{20}$ que assinam a carta, habitavam o território hoje em disputa "sem serem importunadas em suas vidas e atividades por não indígenas" (Silva, 2013) até as décadas de 1940 e 1950, quando projeto de ocupação agrícola do governo Vargas trouxe uma grande leva de gaúchos e paulistas para a região, e os índios foram progressivamente sendo mais e mais "despejados" em reservas (Brand, 1998). Aqueles que ficaram fora das reservas vivem em situações de extrema precariedade, ao mesmo tempo que buscam o retorno a seus territórios antigos de modo a reconstruírem seu tekoha. Tekoha "é o lugar e o meio em que se dão as condições de possibilidade do modo de ser guarani" (Meliá, 2010); é o termo que sintetiza o vínculo complexo entre modo de ocupação do espaço através de um constante caminhar (oguata), ${ }^{21}$ vivência comunitária e sentido cosmogônico, como veremos na leitura da Carta.

\section{A carta}

A carta é anunciada como "Carta da comunidade Guarani-Kaiowá de Pyelito Kue/Mbarakay-Iguatemi-MS para o Governo e Justiça do Brasil"

Nós (50 homens, 50 mulheres e 70 crianças) comunidades Guarani-Kaiowá originárias do tekoha Pyelito Kue/Mbarakay, viemos através desta carta apresentar a nossa situação histórica e decisão definitiva diante da ordem de despacho expressa pela Justiça Federal de Navirai-MS, conforme o processo $n^{\circ} 0000032-$ 87.2012.4.03.6006, do dia 29 de setembro de 2012.

Um ano e dois meses antes da divulgação da Carta, e após três dias e noites de reza preparatórias para o caminho de volta, a comunidade Pyelito Kue/Mbarakay retorna ao seu tekoha, no dia 8 de agosto de 2011, informando que, dessa vez, não sairá mais de lá até a demarcação. ${ }^{22}$

\footnotetext{
20 "Pyelito" é o modo como pronunciam "pueblito", pequeno povoado, no seu dialeto guarani, e Kue é partícula que indica passado: "assim, 'Pyelito Kue' designa 'o [lugar] que era o Pyelito"” (Silva, 2013). Mbarakay é o nome do outro grupo familiar, que, junto com Pyelito, tentam o retorno a seu tekoha.

${ }^{21}$ Como ressalta texto do Instituto Socioambiental: "Entre estes tekoha e por todo o território guarani, processam-se as mais variadas formas de efervescente movimento de traslados orientados por relações familiares. Esse constante caminhar (oguata) pode representar visitas, mudanças, passagem, casamentos, etc." (ISA, s.d.).

${ }^{22}$ Para compor essa narrativa resumida, vali-me das várias informações veiculadas pelo site do Conselho Indigenista Missionário (Cimi), que acompanha caso a caso os eventos envolvendo os
} 
Essa é a terceira tentativa de retorno: tanto na primeira, em julho de 2003, como na segunda, em dezembro de 2009, o grupo foi espancado e jogado à beira da estrada por pistoleiros a mando de fazendeiros da região. Em 2011, o mesmo procedimento vai se repetir até o impacto da Carta que será veiculada em 8 de outubro de 2012. Inicialmente, o grupo acampara em área da fazenda Santa Catarina. Foram atacados, seus barracos destruídos e suas lonas confiscadas, conforme documento encaminhado às autoridades pela Assembleia Aty Guasu. Em 5 de setembro de 2011, aqueles que ainda permaneciam no local são violentamente expulsos para a margem do rio Hovy e ali ficam isolados, impedidos de atravessarem para a outra margem, pois as pontes de cipós que constroem são constantemente destruídas. As polícias militar e civil do Estado chegam a fazer barreira nas estradas vizinhas para impedir que se leve comida aos índios, segundo nota pública de denúncia lançada pelo Cimi no dia 9 de setembro de 2011. Em novembro de 2011, outra assembleia da Aty Guasu publica uma "Declaração contra ameaças de morte" e relata outro caso estarrecedor: uma comitiva da Presidência da República ${ }^{23}$ foi ao local do conflito. Mesmo escoltado por equipe da Força Nacional de Segurança Pública, ao retornar com as lideranças indígenas, o grupo é ameaçado na estrada por quatro ocupantes de um veículo que os filmava: “Um deles se apresentou como prefeito de Iguatemi, e outro, como presidente do Sindicato Rural de Iguatemi-MS. Os dois são fazendeiros da região de Pyelito Kue-Mbarakay" (Cimi).

A situação precária dos índios isolados na margem do rio persiste, até que em 17 de setembro 2012, o juiz federal Sergio Henrique Bonachela dá ganho de causa ao proprietário da Fazenda Cambará, determinando a manutenção de posse e a retirada dos índios. É então que a Carta é enviada por correio eletrônico a Egon Heck, do Conselho Missionário Indigenista (Cimi), acompanhada de um relatório da Aty Guasu, que conclui: "Não é possível despejar indígenas da margem de um rio" (Heck, 2012).

Guarani Kaiowá no Mato Grosso do Sul. Para uma consulta direcionada, basta digitar em seu sistema de busca a palavra, "Pyelito Kue", e todas as notícias relativas ao caso desde 2011 encontram-se lá.

${ }^{23}$ Integram a comitiva o Secretário de Articulação Social da Secretaria-Geral da Presidência, Paulo Maldos, e dois membros da Secretaria de Direitos Humanos. 
Recebemos esta informação de que nós comunidades, logo seremos atacada, violentada e expulsa da margem do rio pela própria Justiça Federal de Navirai-MS. Assim, fica evidente para nós, que a própria ação da Justiça Federal gera e aumenta as violências contra as nossas vidas, ignorando os nossos direitos de sobreviver na margem de um rio e próximo de nosso território tradicional Pyelito Kue/Mbarakay.

Qualquer conhecedor da literatura latino-americana sabe a importância da margem, e no caso específico brasileiro, da importância da margem de um rio, simbolizada por João Guimarães Rosa no conto publicado em Primeiras estórias, "A terceira margem do rio". Trata-se aqui da margem do rio Hovy:

A quem vamos denunciar as violências praticadas contra nossas vidas? Para qual Justiça do Brasil? Se a própria Justiça Federal está gerando e alimentando violências contra nós? Nós já avaliamos a nossa situação atual e concluímos que vamos morrer todos mesmo em pouco tempo, não temos e nem teremos perspectiva de vida digna e justa, tanto aqui na margem do rio, quanto longe daqui.

"A terceira margem do rio" já foi analisada como território dos mortos (Wisnik, 2004). No conto, o filho fica sempre à margem, à espera do pai, e quando chega sua hora de ocupar o espaço do meio do rio, na canoa, o filho receia, vacila e foge, e o conto é também o relato dessa culpa. Ao recebermos a Carta Guarani Kaiowá/Pyelito Kue/Mbarakay estamos postos, nós leitores, na mesma posição desse filho: por isso, a reação de muitos foi adotar o sobrenome Guarani Kaiowá, que continuam usando nas redes sociais até hoje. Ao dizerem: "não temos e nem teremos perspectiva de vida digna e justa, tanto aqui na margem do rio quanto longe daqui", esses pobres, miseráveis e famintos nos apelam para o meio simbólico que habitamos: o fosso, a vala comum, a morte continuada e impune, ou se alguma redenção no meio do rio e na sua terceira margem será possível.

Estamos aqui acampados a 50 metros do rio Hovy, onde já ocorreram quatro mortes, sendo duas por meio de suicídio e duas em decorrência de espancamento e tortura de pistoleiros das fazendas. Moramos na margem do rio Hovy há mais de um ano e estamos sem assistência nenhuma, isolados, cercados de pistoleiros e resistimos até hoje. Comemos comida uma vez por 
dia. Passamos tudo isso para recuperar o nosso território antigo Pyelito Kue/Mbarakay.

A resposta Guarani Kaiowá é uma voz fina e mutilada, e é do meio dessa fraqueza que aponta para a fraude, a covardia e a matança que a história do Brasil sempre "transcendeu", infelizmente, com o auxílio de boa parte de sua literatura.

De fato, sabemos muito bem que no centro desse nosso território antigo estão enterrados vários de nossos avôs e avós, bisavôs e bisavós, ali estão os cemitérios de todos os nossos antepassados. Cientes desse fato histórico, nós já vamos e queremos ser mortos e enterrados junto aos nossos antepassados aqui mesmo onde estamos hoje. Por isso, pedimos ao Governo e à Justiça Federal para não decretar a ordem de despejo/expulsão, mas decretar nossa morte coletiva e enterrar nós todos aqui.

O Relatório da Funai fala sobre a importância das sepulturas entre os guarani:

Sepultar a pessoa numa terra com a qual não guarda uma relação de identidade, ou seja, à qual ela não pertence, constitui uma anomalia de difícil equação em termos cosmológicos e espirituais para os Kaiowá, constituindo-se em algo que deve ter, em algum momento, conserto para que o ordenamento sociocosmológico se torne aquele que deve ser, o correto. Por constituírem um indício significativo e materialmente visível da ligação dos indígenas com seu território, uma prática generalizada foi a de os proprietários não indígenas destruírem as sepulturas (yta) que se encontravam nos limites das fazendas [...] (Silva, 2013).

E aqui vem a sentença principal, a força desse apelo ao revés, pois em nossa lógica ninguém pede para ser morto, a não ser que esteja em condições tão miseráveis e insuportáveis, que a vida não valha nem salve:

Pedimos, de uma vez por todas, para decretar nossa dizimação e extinção total, além de enviar vários tratores para cavar um grande buraco para jogar e enterrar os nossos corpos. Esse é nosso pedido aos juízes federais. Já aguardamos esta decisão da Justiça Federal. Decretem a nossa morte coletiva Guarani e Kaiowá de Pyelito Kue/Mbarakay e enterrem-nos aqui. Visto que decidimos integralmente a não sairmos daqui com vida e nem mortos. 
A precisão é importante: não sairão dali "com vida", ou seja, expulsos como sempre foram; e também não sairão dali "nem mortos", semelhante à expressão "nem que me matem", para manifestar recusa total a qualquer tipo de remoção, por isso o pedido muito concreto aos juízes federais: "enterrem-nos aqui" e enviem tratores para cavar o buraco. Não se trata, assim, de uma reivindicação para viverem na terra que lhes pertencia, pois já não esperam mais esse direito sempre negado, mas da solicitação de uma cova, "um grande buraco para jogar e enterrar nossos corpos", porque assim não sairão da terra em que estão seus ancestrais. Esse pedido é inédito e inverso à lógica ruralista de ocupação de enormes territórios para algumas centenas de bois ou para a produção em larga escala da soja ou da cana, baseados em uso explorador da terra. “O Guarani não deixa desertos atrás de si" (Meliá, 1990, p. 36), explica um de seus principais estudiosos, remetendo ao conceito de tekoha, ao qual aludimos anteriormente. Começamos a entendê-lo melhor, a partir do pedido dessa carta, que nos revela o quão intenso é o sentido do vínculo com a terra, um vínculo que pode ser traduzido em nossos termos como "poético", pois está também ligado à noção da palavra "com terra", e não apenas "com papel", que citamos inicialmente. ${ }^{24}$

Sabemos que não temos mais chance de sobreviver dignamente aqui em nosso território antigo. Já sofremos muito e estamos todos massacrados e morrendo em ritmo acelerado. Sabemos que seremos expulsos daqui da margem do rio pela Justiça, porém não vamos sair da margem do rio. Como um povo nativo e indígena histórico, decidimos meramente em sermos mortos coletivamente aqui. Não temos outra opção, esta é a nossa última decisão unânime diante do despacho da Justiça Federal de Navirai-MS.

E o texto conclui com a formalidade das missivas, como se o que acabasse de enunciar não impossibilitasse a gentileza final para com seus violentadores: "Atenciosamente, Guarani-Kaiowá de Pyelito Kue/Mbarakay".

\footnotetext{
${ }^{24}$ Em seu estudo etnológico que resulta de uma convivência e participação em vários rituais e caminhadas do grupo Kaiowá na área de Dourados, Mato Grosso do Sul, sintetiza Gabriela Chamorro: "A terra Kaiowá e Mbyá é comparada a um corpo murmurante. O mundo vem à existência pela palavra. Antes da criação, a palavra já murmurava nas entranhas da matéria" (Chamorro, 2008, p. 25).
} 


\section{Pós-carta}

Após o impacto gerado pela carta, a decisão judicial foi suspensa, e aos índios ficou reservada uma área onde estão vivendo à espera do processo de demarcação. Em janeiro de 2013, foi aprovado e publicado no Diário Oficial da União o Relatório circunstanciado de identificação e delimitação da terra indígena Iguatemipegua (Silva, 2013), assinado pela antropóloga que coordena a equipe da Funai. No momento em que escrevo, a comunidade Pyelito Kue/Mbarakay continua a viver em um hectare de terra, com poucas condições de deslocamento, à espera do prazo de 90 dias seguido de outros 60 dias para avaliação e encaminhamento ao Ministério da Justiça. O fato é que há 46 fazendas no território reconhecido (de 41.571 hectares), e nada será feito enquanto governo e fazendeiros não chegarem a um acordo sobre indenizações. Importa lembrar que, segundo a Constituição de 1988, o processo de demarcação das terras indígenas no país deveria ter sido concluído em 1993. Em 2013, completaram-se vinte anos desde o fim desse prazo. Além disso, como diz o líder Kaiowá Oriel Benites, “[a] terra está voltando [para os indígenas] toda devastada, sem floresta" (Sposati, 2013).

O que a carta põe em jogo é todo um histórico de repressão, etnocídio, genocídio, expondo-o ao inverter o discurso que sempre louvou os índios mortos, enquanto, na prática, continuava-se a ignorar e a exterminar os vivos. Agora, os índios vivos "solicitam" sua morte, pois esta vem sendo perpetrada há séculos, e assim denunciam o crime e, pelo revés, pedem socorro. Ao fazerem isso, eles saem da posição de vítimas sem voz, expondo quem são os assassinos. Sua fraqueza vira força e, por isso, força poética. Diferentemente de outras cartas que vêm circulando nas redes, a dramaticidade desse texto se manifesta em sua dicção retorcida; a Carta diz, desdizendo; acusando, aponta sua inocência; pedindo para morrer, vive. E assim, ao solicitarem que decretem sua morte, os índios se mostram mais vivos do que nunca. ${ }^{25}$

\footnotetext{
25 "Essa carta furou o muro de silêncio hipócrita que costuma impedir que as vozes indígenas sejam ouvidas pelos demais cidadãos do país e, graças ao circuito informal das redes sociais da internet, acabou tendo que ser divulgada pela mídia convencional. Quando todos - todos, isto é, todos aqueles que dizemos 'todos' como um grito de raiva e de guerra - passaram a se assinar 'Fulano Guarani Kaiowá', era como se o Brasil tivesse descoberto outro Brasil”' (Viveiros de Castro, 2013).
} 


\section{Paragens: 0 direito à terra e à literatura}

Jacques Derrida, no último capítulo de seu livro Parages, relembra a "nobre tradição política e literária francesa" (2003, p. 272) que, de Voltaire a Camus, defende a literatura como direito à vida: "o direito da literatura, o direito à literatura não como direito à morte - e ao terror mas como o direito à vida, direito para-além do direito e direito à abolição da pena de morte" (Derrida, 2003, p. 272, tradução nossa). Derrida passa então a comentar texto de Maurice Blanchot "La littérature et le droit à la mort", que parece indicar o sentido contrário: a literatura como direito à morte, expressão maior da liberdade revolucionária durante o período do Terror na Revolução Francesa. O livro La Part du Feu, de Blanchot, lembra Derrida, foi publicado um ano após a Declaração Universal dos Direitos Humanos, de 1948, por sua vez, escrita cem anos depois de 1848, quando Victor Hugo vota pela abolição da pena de morte no contexto do Terror revolucionário. Do texto de Blanchot comentado por Derrida, importa destacar a seguinte passagem, útil para entender a torsão operada pela Carta Guarani Kaiowá:

Esse é o sentido do Terror. Cada cidadão tem, por assim dizer, direito à morte: a morte não é sua condenação, é a essência de seu direito; ele [o cidadão] não é eliminado [suprimé] como culpado, mas precisa da morte para se afirmar cidadão e é a partir do desaparecimento da morte que a liberdade o faz nascer (Blanchot, 1949, citado por Derrida, 2003, p. 277).

Não parece estranho que essas palavras aplicadas ao acontecimento da Revolução Francesa se adequem ou se encaixem perfeitamente ao gesto da Carta Guarani Kaiowá? Não é exatamente isso que estão dizendo? A morte não é nossa condenação, mas a essência de nosso direito? O de sermos enterrados no terreno de nossos antepassados, na terra que sempre foi nossa por direito negado e suprimido desde a conquista? E não é isso que pedem, exigem mesmo, do governo brasileiro: decretem a nossa morte coletiva e tragam tratores para cavar nossa cova? Não é esse um gesto de máxima liberdade: a libertação do Terror (esse sim) do massacre sempre disfarçado impetrado contra eles?

$\mathrm{O}$ direito da literatura à morte é o mesmo que está na origem do direito como tal, diz Derrida, o direito de matar, de se matar, e da pena de morte. Mas há uma outra face desse debate que nos faz sair do terror que ela anuncia; e Derrida enumera: 1) a linguagem literária é 
contraditória e inquieta (diz uma coisa e é outra que aparece; 2) o princípio de morte é também princípio de ressureição e saúde, e a esperança está na materialidade da linguagem, pois as palavras são coisas que nos dão mais do que compreendemos; e 3) Blanchot fala da morte como impossibilidade de morrer.

Reivindicar a inclusão da Carta Pyelito Kue/Mbarakay como parte de "nossa" literatura significa então apelar para dois movimentos: 1) o de minar o "nossa" pela sua ampliação e tirar-nos do domínio colonialista, fazendo com que esse nosso seja, também, o dos nativos. E, de novo, não se trata de inclusão caritativa ou inclusão que elimina a diferença, mas inclusão deles como grupo produtor de texto, enunciadores de sua história, donos de sua voz, aquilo que em nosso regime discursivo chamamos "autores", o direito à literatura como o direito à autoria, à autoridade e à assinatura; e 2) o direito à literatura como reversão da pena de morte, pois que no nosso, e agora me refiro ao Ocidental sistema discursivo, há um terreno ao qual se reserva a possibilidade (que venha a ocorrer ou não é tarefa delegada aos leitores) de uma sobrevida: esse terreno é o arquivo escrito que vai formar parte de uma tradição que os mortos deixam aos vivos e com eles dialogam. Esse é o sentido do direito à literatura enunciado por Brás Cubas e que parece fazer par com Blanchot/Derrida: "como se a morte se inscrevesse enquanto acontecimento inevitável no processo que faz de alguém um autor: como se, em contrapartida, todo o autor estivesse impossibilitado de morrer. O que aqui se anuncia, na ficção e pela ficção, é a presença inelutável da morte na própria destinação do texto literário" (Baptista, 2005, p. 166).

\section{De Caminha ao caminhar}

Nesse contexto, a pequena e incisiva Carta Guarani Kaiowá torna-se a nova Carta de Caminha, só que ao revés. Se esta era a Carta de "Achamento do Brasil", aquela é a Carta de Fechamento do Brasil, entendendo pelo termo tanto o fim geral do Brasil, que ou vai desaparecer nas cinzas de seu próprio fogo, brasa que não cessa de incendiar povos e gentes de sua história, de sua flora e de sua fauna; ou o fim, apenas, do Brasil maior que a primeira carta inaugurava, mostrando-se, pois, como possibilidade, ainda aberta, de um Brasil menor que aí sempre esteve e continuará a estar. Se a carta de Pero Vaz de Caminha (que apenas no século XIX entra para as histórias literárias) 
dava notícias do "achamento" da Terra de Santa Cruz, a carta assinada por cinquenta mulheres, cinquenta homens e cinquenta crianças da comunidade Pyelito Kue/Mbarakay fecha um ciclo de cinco séculos e com isso inaugura a possibilidade de outros futuros. Se a carta de Caminha se endereçava ao Rei, a carta Kaiowá se endereça à Justiça brasileira. Se a carta de Caminha dava início escrito ao processo de colonização, a Carta Guarani Kaiowá se institui como o documento descolonial por excelência. No entanto, há uma diferença ainda mais radical, como vimos discutindo: se a carta de Caminha dava notícia dos índios vivos que o redator encontrou no Brasil, a carta Kaiowá dá notícia de sua morte coletiva iminente. No primeiro caso, trata-se de uma carta inaugural; no segundo caso, trata-se de uma carta de despedida. Acontece que aqui, como um quiasma, as coisas se invertem: no primeiro caso, os índios vivos darão lugar aos milhares de exterminados por guerras e epidemias; no segundo caso, os índios em via de desaparecimento darão lugar à sua multiplicação e vão renascer com a força de sua palavra. No primeiro caso, os brasileiros vão nascer como os mestiços daquele encontro e confronto, e o pau-brasil dará início a árvore genealógica brasileira; no segundo caso, os brasileiros vão retornar como nativos, parte da família extensa Guaranis Kaiowás a se espalhar nos rizomas das redes. Sua repercussão deu-nos, de fato, a chance de afirmar "no Brasil todo mundo é índio, inclusive eu", 26 e meu nome é Guarani Kaiowá, Munduruku, Kadiwéu e Canela, como o belo poema "Totem", de André Vallias, condensou. ${ }^{27}$ A força poética e política da Carta de Pyelito Kue/Mbarakay é o que este texto buscou descrever.

\footnotetext{
${ }^{26}$ Frase que retoma a famosa sentença de Viveiros de Castro (2007), "No Brasil, todo mundo é índio, exceto quem não é".

${ }^{27}$ Veja-se o belo e forte poema "Totem" de André Vallias (2013), que condensa todos os nomes das tribos indígenas do Brasil, e o seguinte comentário de Viveiros de Castro (2013), que o acompanha: “Os índios não são 'nossos índios'. Eles não são 'nossos'. Eles são nós. Nós somos eles. Todos nós somos todos eles. Somos outros, como todos. Somos deste outro país, esta terra vasta que se vai devastando, onde ainda ecoam centenas, milhares de gentílicos, etnônimos, nomes de povos, palavras estranhas, gramáticas misteriosas, sons inauditos, sílabas pedregosas mas também ditongos doces, palavras que escondem gentes e línguas de que sequer suspeitávamos os nomes.”
} 


\section{Referências}

ALMEIDA, Rubem Ferreira Thomaz de (2001). Do desenvolvimento comunitário à mobilização politica: o projeto Kaiowá-Ñandeva como experiência antropológica. Rio de Janeiro: Contra Capa.

AGUILAR, Gonzalo; NODARI, Alexandre (2010). Por una ciencia del vestigio errático (Ensayos sobre la antropofagia de Oswald de Andrade) seguido de "La única ley del mundo", de Alexandre Nodari. Buenos Aires: Grumo.

BAPTISTA, Abel Barros (2005). O livro agreste. Campinas: UNICAMP.

BAPTISTA, Abel Barros (2009). Ideia de literatura brasileira com propósito cosmopolita. Revista Brasileira de Literatura Comparada, n. 15, p. 61-87.

BAPTISTA, Abel Barros (2011). Roça barroca. São Paulo: Cosac Naify.

BRAGA, Fabio William Lopes (2009). A Carta de Caminha e o conceito de literatura na historiografia literária brasileira. Dissertação (Mestrado em Literatura) Universidade Estadual Paulista (UNESP), São Paulo.

BRAND, Antonio J. (1998). O impacto da perda da terra sobre a tradição kaiowá/guarani: os difíceis caminhos da Palavra. Tese (Doutorado em História) Pontifícia Universidade Católica do Rio Grande do Sul (PUC-RS), Porto Alegre.

BROTHERSTON, Gordon (2007). Popol Vuh: Contexto e princípios de leitura. In: Brotherston, Gordon; Medeiros, Sérgio (Org.). Popol Vuh. São Paulo: Iluminuras. p. 11-37.

BRUM, Eliane (2012a). Decretem nossa extinção e nos enterrem aqui. Época, 22 out. Disponível em: http://revistaepoca.globo.com/Sociedade/elianebrum/noticia/2012/10/ decretem-nossa-extincao-e-nos-enterrem-aqui.html. Acesso em: 23 out. 2012.

BRUM, Eliane (2012b). Sobrenome: Guarani Kaiowá. Época, 26 nov. Disponível em: <http://goo.gl/TMeMj>. Acesso em: 10 abr. 2013.

CANDIDO, Antonio (1981). Formação da literatura brasileira. Belo Horizonte: 1tatiaia.

CANDIDO, Antonio (2004 [1998]). O direito à literatura. In: - Vários escritos. Rio de Janeiro: Ouro sobre Azul; São Paulo: Duas Cidades, p. 169-191.

CASTELLO, José Aderaldo (1999). A literatura brasileira: origens e unidade. São Paulo: EDUSP.

CESARINO, Pedro de Niemeyer (2009). Os poetas. Folha de S. Paulo, São Paulo, 18 jan. Caderno Mais. Disponível em: <http://goo.gl/ZNzzhf>. Acesso em: 30 jan. 2013. 
CHAMORRO, Gabriela (2008). Terra madura Yvi Araguyge: fundamento da palavra guarani. Dourados: UFGD.

COHN, Sergio (Org.) (2012). Poesia.br. Rio de Janeiro: Azougue.

CONSELHO/COMISSÃO DE ATY GUASU GUARANI E KAIOWÁ DO MS (2012). Carta Guarani Kaiowá de Pyelito Kue/Mbarakay. Conselho Indigenista Missionário (website). Brasília: CNBB, 8 out. Disponível em: <http://goo.gl/GWZy2l>. Acesso em: 20 out. 2012.

COSTA LIMA, Luiz (2006). História. Ficção. Literatura. São Paulo: Companhia das Letras.

CUNHA, Manuela Carneiro da (2012). Índios no Brasil: história, direitos e cidadania. São Paulo: Claro Enigma.

DERRIDA, Jacques (2003). Maurice Blanchot est mort. Parages. Paris: Galilée, p. 267-300.

DIEGUES, Douglas (Org.) (2006). Kosmofonia Mbya-Guarani. São Paulo: Mendonça \& Provazi.

FARIA, Francisco (2011). Notas sobre um percurso compartilhado. In: BAPTISTA, Josely Vianna. Roça barroca. São Paulo: Cosac Naify, p. 139-148.

FRANCHETTI, Paulo (2002). História literária: um gênero em crise. Revista Semear, Rio de Janeiro, n. 7, p. 247-264. Disponível em: <http://goo.gl/pH0A5k>. Acesso em: 22 jul. 2012.

GINSZBURG, Jaime (2012). Crítica em tempos de violência. São Paulo: EDUSP; FAPESP.

HECK, Egon (2012). Indígenas ameaçam morrer coletivamente caso ordem de despejo seja efetivada. Conselho Indigenista Missionário. Brasília: CNBB. Disponível em: http://www.cimi.org.br/site/ptbr $/$ ?system=news\&action=read\&id=6553. Acesso em: 9 nov. 2012.

INSTITUTO SOCIOAMBIENTAL (ISA) (s.d.). Guarani Kaiowá. Povos indígenas no Brasil (website). [s.1.]: ISA. Disponível em: http://pib.socioambiental.org/pt/povo/guarani-kaiowa/554. Acesso em: 20 jan. 2013.

LIBRANDI-ROCHA, Marília (2012). Escutar a escrita: por uma teoria literária ameríndia. O Eixo e a Roda, v. 21, n. 2 (edição especial), p. 179-202.

LIDERANÇA Guarani Kaiowá denuncia ataque de pistoleiros ao tekoha Pyelito Kue. Conselho Missionário Indígena (Cimi), $1^{\mathrm{o}}$ mar. 2014. Disponível em: http://www.cimi.org.br/site/pt-br/?system=news\&action=read\&id=7389.

Acesso em: 8 set. 2014. 
MELIÁ, Bartolomeu (1990). A terra sem mal dos Guarani. Revista de Antropologia, São Paulo, v. 33, p. 33-46.

MELIÁ, Bartolomeu (2010). A história de um guarani é a história de suas palavras. Revista IHU Online, n. 331. Disponível em: http:/ / www.ihuonline.unisinos.br/index.php?option=com_content\&view=arti cle\&id=3258\&secao=331. Acesso em: 28 jan. 2013.

MONTEIRO, John Manuel (1992). Os Guarani e a história do Brasil meridional: séculos XVI-XVII. In: CUNHA, Manuela Carneiro da (Org.). Historia dos índios do Brasil. São Paulo: Fapesp; SMS; Companhia das Letras. p. 475-500.

MORAES, Anita M. R. de (2012). Da natureza à cultura: literatura e folclore no pensamento de Antonio Candido. In: BRASA CONFERENCE, 11, ChampaignUrbana. Anais... Disponível em: <http://goo.gl/6s1ZJy>. Acesso em: 22 fev. 2013.

MOTA, Juliana Grasiéli Bueno (2011). Territórios e territorialidades Guarani e Kaiowá: da territorialização precária na reserva indígena de Dourados à multiterritorialidade. Dissertação (Mestrado em Geografia) - Universidade Federal da Grande Dourados (UFGD), Dourados.

NATALI, Marcos Piason (2006). Além da literatura. Literatura e Sociedade, São Paulo, v. 9, p. 30-43.

OLIVIERI-GODET, Rita (2012).Traumas e travessias: a alteridade ameríndia e as fronteiras simbólicas da nação. Estudos de Literatura Brasileira Contemporânea, Brasília, n. 40, p. 63-79.

RISÉRIO, Antonio (1993). Textos e tribos: poéticas extraocidentais nos trópicos brasileiros. São Paulo: Imago.

RONCARI, Luiz (2002). Literatura brasileira: dos primeiros cronistas aos últimos românticos. 2. ed. São Paulo: Edusp.

SÁ, Lúcia (2004). Rain Forest literatures: Amazonian texts and Latin American literature. University of Minnesota Press.

SCHEIBE, Fernando (2013). Ainda brasileira?: literatura, ensino e a comunidade fundada na ausência de comunidade. Sopro, n. 86. Disponível em: <http://goo.gl/0MHTYx>. Acesso em: 18 fev. 2013.

SILVA, Alexandra Barbosa da (2013). Relatório circunstanciado de identificação e delimitação da terra indígena Iguatemipegua I (Mbarakay e Pyelito). Resumo. Brasília: FUNAI. Disponível em: <http://goo.gl/jX52L>. Acesso em: 20 abr. 2013.

SPOSATI, Ruy (2013). Ainda estamos vivendo em um hectare de terra Conselho Indigenista Missionário (website). Brasília: CNBB. Disponível em: http:/ / www.cimi.org.br/site/pt-br/?system=news\&action=read\&id=6698. 
VALLIAS, André (2013). Totem. Folha de S. Paulo, 6 jan. Ilustríssima. Disponível em vídeo em: http://revistamododeusar.blogspot.com/2013/01/totem-2013de-andre-mvallias.html. Acesso em: 27 mar. 2013.

VIVEIROS DE CASTRO, Eduardo (2002). A inconstância da alma selvagem e outros ensaios de antropologia. São Paulo: Cosac \& Naify.

VIVEIROS DE CASTRO, Eduardo (2004). Perspectival anthropology and the method of the controled equivocation. Tipití, v. 2, n. 1, p. 3-12.

VIVEIROS DE CASTRO, Eduardo (2007). Entrevistas. Organização de Renato Sztutman. Rio de Janeiro: Azougue.

VIVEIROS DE CASTRO, Eduardo (2013). Somos todos eles: o poema onomatotêmico de André Vallias. Revista Modo de Usar, Rio de Janeiro, 14 jan. Disponível em: http://revistamododeusar.blogspot.com/2013/01/totem-2013de-andre-vallias.html. Acesso em: 23 abril 2013.

WISNIK, José Miguel (2004). A gaia ciência: literatura e música popular no Brasil. In: WISNIK, José Miguel. Sem receita. São Paulo: Publifolha.

Recebido em abril de 2014.

Aprovado em maio de 2014.

\section{resumo/abstract}

\section{A Carta Guarani Kaiowá e o direito a uma literatura com terra e das gentes}

Marília Librandi-Rocha

Este artigo propõe incluir a Carta Guarani Kaiowá no campo da literatura contemporânea produzida no Brasil. Essa inclusão impõe desafios teóricos em relação ao que entendemos por literatura, quais suas relações com os direitos humanos no âmbito dos estudos culturais, além de exigir um enfrentamento com a história literária do Brasil. O objetivo é pensar não apenas "nossa" literatura, historicamente vinculada ao sistema colonial e depois nacional, mas pensar uma literatura vinculada à terra, e não apenas da gente do Brasil, mas das gentes da América do Sul.

Palavras-chave: Guarani Kaiowá, tekoha, história literária brasileira, literatura ameríndia. 
The Guarani Kaiowá's Letter and the right to a literature with land and from the pluralities of people

Marília Librandi-Rocha

This article proposes to consider the Guarani Kaiowa's Letter as part of contemporary Literature produced in Brazil. This inclusion presents itself as a theoretical challenge because it obligates us to explicit what we understand by "literature", its connections to Human Rights, and which place this letter occupies within the history of Brazilian literature. The final aim is to think not only about "our" literature, historically linked to the colonial and then to the national system, but about a post-colonial literature produced and signed by the pluralities of people living in Brazil.

Keywords: Guarani Kaiowá, tekoha, Brazilian literary history, Amerindian literature. 